\title{
Mercury isotope fractionation during ore retorting in the Almadén mining district, Spain
}

\author{
John E. Gray ${ }^{\mathrm{a}, *}$, Michael J. Pribil ${ }^{\mathrm{a}}$, Pablo L. Higueras ${ }^{\mathrm{b}}$ \\ a U.S. Geological Survey, P.O. Box 25046, MS 973, Denver, CO 80225, USA \\ ${ }^{\mathrm{b}}$ Universidad de Castilla-La Mancha, Plaza M. Meca 1, 13400 Almadén, Spain
}

\section{A R T I C L E I N F O}

Article history:

Received 28 May 2013

Received in revised form 20 August 2013

Accepted 22 August 2013

Available online 30 August 2013

Editor: J. Fein

\section{Keywords:}

Mercury isotopes

Retorting

Cinnabar ore

Mine waste calcine

Mass dependent fractionation

\begin{abstract}
A B S T R A C T
Almadén, Spain, is the world's largest mercury (Hg) mining district, which has produced over 250,000 metric tons of $\mathrm{Hg}$ representing about 30\% of the historical $\mathrm{Hg}$ produced worldwide. The objective of this study was to measure $\mathrm{Hg}$ isotopic compositions of cinnabar ore, mine waste calcine (retorted ore), elemental $\mathrm{Hg}\left(\mathrm{Hg}_{(\mathrm{L})}^{\mathrm{O}}\right)$, and elemental $\mathrm{Hg}$ gas $\left(\mathrm{Hg}^{0}{ }_{(\mathrm{g})}\right)$, to evaluate potential $\mathrm{Hg}$ isotopic fractionation. Almadén cinnabar ore $\delta^{202} \mathrm{Hg}$ varied from -0.92 to $0.15 \%$ ( and $\delta^{202} \mathrm{Hg}$ ranged from $-0.03 \%$ o to $1.01 \%$ (mean of $0.43 \%, \sigma=0.44 \%, \mathrm{n}=8$ ). The average $\delta^{202} \mathrm{Hg}$ enrichment of $0.99 \%$ between cinnabar ore and calcines generated during ore retorting indicated $\mathrm{Hg}$ isotopic mass dependent fractionation (MDF). Mass independent fractionation (MIF) was not observed in any of the samples in this study. Laboratory retorting experiments of cinnabar also were carried out to evaluate $\mathrm{Hg}$ isotopic fractionation of products generated during retorting such as calcine, $\mathrm{Hg}_{(\mathrm{L})}{ }^{\mathrm{L}}$, and $\mathrm{Hg}_{(\mathrm{g})}^{0}$. Calcine and $\mathrm{Hg}_{(\mathrm{L})}^{0}$ generated during these retorting experiments showed an enrichment in $\delta^{202} \mathrm{Hg}$ of as much as $1.90 \%$ and $0.67 \%$, respectively, compared to the original cinnabar ore. The $\delta^{202} \mathrm{Hg}_{\text {for }} \mathrm{Hg}_{(\mathrm{g})}^{0}$ generated during the retorting experiments was as much as $1.16 \%$ isotopically lighter compared to cinnabar, thus, when cinnabar ore was roasted, the resultant calcines formed were isotopically heavier, whereas the $\mathrm{Hg}_{(\mathrm{g})}^{0}$ generated was isotopically lighter in $\mathrm{Hg}$ isotopes.
\end{abstract}

Published by Elsevier B.V.

\section{Introduction}

Areas in and around $\mathrm{Hg}$ mines contain some of the highest concentrations of Hg worldwide (Gosar et al., 1997; Rytuba, 2000; Bailey et al., 2002; Gray et al., 2003; Feng and Qiu, 2008). Active and inactive $\mathrm{Hg}$ mines are of potential environmental concern because of high concentrations of $\mathrm{Hg}$ ( $>1 \%$ in some areas) present in discarded mine wastes, including calcine at these sites (Gray et al., 2000; Higueras et al., 2003; Lin et al., 2010; Rimondi et al., 2012; Yin et al., 2013). Cinnabar (hexagonal, $\mathrm{HgS}$ ) is the dominant $\mathrm{Hg}$-bearing ore mineral in $\mathrm{Hg}$ mines worldwide,

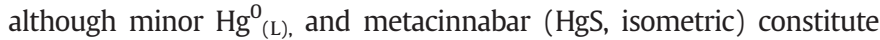
ore in some deposits including Almadén (Gray et al., 2004; Stetson et al., 2009). Extraction of $\mathrm{Hg}$ during mining is generally carried out in a retort or a rotary furnace where cinnabar ore is heated to temperatures of $600-700{ }^{\circ} \mathrm{C}$, which converts cinnabar to $\mathrm{Hg}^{0}(\mathrm{~L})$, the final product sold commercially. Retorting of $\mathrm{Hg}$-bearing ore is known to be an incomplete process, and as a result, calcine found at most $\mathrm{Hg}$ mines contains unconverted cinnabar, $\mathrm{Hg}_{(\mathrm{L})}^{0}$, metacinnabar, and other $\mathrm{Hg}$ by-product compounds formed during ore retorting (Kim et al., 2000; Kim et al., 2003; Gray et al., 2010). Studies have reported the presence of minor

\footnotetext{
* Corresponding author at: U.S. Geological Survey, Denver Federal Center, P.O. Box 25046, MS 973, Denver, CO 80225 USA. Tel.: +1 303236 2446; fax: +1 3032363200. E-mail address: jgray@usgs.gov (J.E. Gray).
}

by-product compounds such as calomel $\left(\mathrm{Hg}_{2} \mathrm{Cl}_{2}\right)$, corderoite $\left(\mathrm{Hg}_{3} \mathrm{~S}_{2} \mathrm{Cl}_{2}\right)$, montroydite $(\mathrm{HgO})$, kleinite $\left(\mathrm{Hg}_{2} \mathrm{~N}\left(\mathrm{Cl}_{,} \mathrm{SO}_{4}\right) \cdot \mathrm{n}\left(\mathrm{H}_{2} \mathrm{O}\right)\right)$, terlinguaite $\left(\mathrm{Hg}^{+} \mathrm{Hg}^{2+} \mathrm{ClO}\right)$, gianellaite $\left(\mathrm{Hg}_{4}\left(\mathrm{SO}_{4}\right) \mathrm{N}_{2}\right)$, and schuetteite $\left(\mathrm{Hg}_{3}\left(\mathrm{SO}_{4}\right) \mathrm{O}_{2}\right)$ in calcine (Kim et al., 2000; Gray et al., 2010). Calcine samples in the Almadén district were reported to contain about 99\% cinnabar + metacinnabar $+\mathrm{Hg}_{(\mathrm{L})}^{\mathrm{O}}$, and thus, other minor by-product $\mathrm{Hg}$ compounds comprise $<1 \%$ of the total $\mathrm{Hg}$ in Almadén calcine (Gray et al., 2010).

The world's largest Hg mining district is Almadén, Spain, which has produced over 250,000 metric tons of Hg during more than 2000 years of mining, representing about $30 \%$ of the total $\mathrm{Hg}$ produced worldwide (Hernandez et al., 1999). Mining of ore at Almadén ceased in May 2002, but retorting of stockpiled cinnabar ore continued into February 2004 (Gray et al., 2004). Considerable research has been carried out in the Almadén mining district to evaluate $\mathrm{Hg}$ distribution, speciation, and local effects to the environment (Berzas Nevado et al., 2003; Gray et al. 2004; Bernaus et al., 2006; Higueras et al., 2006; Esbrí et al., 2010; Llanos et al., 2011). However, no studies have attempted to evaluate $\mathrm{Hg}$ isotopic fractionation in ore or mine wastes generated during ore processing at Almadén. Analytical methods for the precise and accurate measurement of the stable isotopes of $\mathrm{Hg}$ have been developed using multicollector-inductively coupled plasma-mass spectrometry (MC-ICPMS) (Hintelmann and Lu, 2003; Foucher and Hintelmann, 2006; Blum and Bergquist, 2007). Using these analytical techniques, previous studies have shown a wide variation of $\mathrm{Hg}$ isotopic compositions in $\mathrm{Hg}$ ores 
(Hintelmann and Lu, 2003; Smith et al., 2005; Stetson et al., 2009). In addition, $\mathrm{Hg}$ isotopic compositions of hydrothermal or volcanic emissions (Smith et al., 2008; Sonke et al., 2008; Sherman et al., 2009; Zambardi et al., 2009) and those interpreted to be of atmospheric origin (Ghosh et al., 2008; Bergquist and Blum, 2009; Carignan et al., 2009; Gratz et al., 2010; Gray et al., 2013) have also been reported. However, there has been no direct measurement of the $\mathrm{Hg}$ isotopic composition of $\mathrm{Hg}_{(\mathrm{g})}^{\mathrm{O}}$ formed during cinnabar ore retorting.

The objectives of this study were to measure the isotopic composition of $\mathrm{Hg}$ in (1) cinnabar from the Almadén $\mathrm{Hg}$ mining district and other cinnabar deposits in Spain to evaluate the isotopic variability within these deposits; (2) calcine, soil, $\mathrm{Hg}_{(\mathrm{L})}^{\mathrm{O}}$, and the mineral schuetteite to evaluate potential isotopic fractionation during ore retorting; and (3) cinnabar ore, calcine, $\mathrm{Hg}_{(\mathrm{L})}^{\mathrm{O}}$, and $\mathrm{Hg}_{(\mathrm{g})}^{\mathrm{O}}$ formed during laboratory retorting experiments to directly evaluate isotopic fractionation of $\mathrm{Hg}$ resulting from cinnabar roasting. The laboratory retorting experiments were designed to replicate large-scale cinnabar retorting typically carried out at $\mathrm{Hg}$ mines worldwide. Other studies have measured the $\mathrm{Hg}$ isotopic compositions of cinnabar ore and mine waste calcine and have suggested $\mathrm{Hg}$ isotopic fractionation during cinnabar ore retorting (Smith et al., 2008; Stetson et al., 2009; Yin et al., 2013). However, the laboratory retort experiments are the first of this kind carried out as there are no known similar studies reported in the scientific literature where there has been direct $\mathrm{Hg}$ isotopic measurement of the $\mathrm{Hg}^{0}{ }_{(\mathrm{L})}$ and $\mathrm{Hg}^{\mathrm{O}}(\mathrm{g})$ products formed during cinnabar ore retorting.

\section{Methods}

\subsection{Sample collection and preparation}

Samples were collected from various locations in the Almadén district (Fig. $1,38^{\circ} 47^{\prime} \mathrm{N}, 4^{\circ} 51^{\prime} \mathrm{W}$ ) and some $\mathrm{Hg}^{0}{ }_{(\mathrm{L})}$ and cinnabar samples were from archived collections. The $\mathrm{Hg}^{0}{ }_{(\mathrm{L})}$ samples consisted of (1) native ore $\mathrm{Hg}^{0}(\mathrm{~L})$, which were collected from wallrock ore, and (2) metallurgical $\mathrm{Hg}^{0}{ }_{(\mathrm{L})}$ produced from retorting of $\mathrm{Hg}$ ore, which were collected from archived $\mathrm{Hg}$ flasks. Thus, the native ore $\mathrm{Hg}^{0}{ }_{(\mathrm{L})}$ samples were naturally occurring and not that produced from ore retorting of cinnabar. Calcine samples were collected as grab samples about $10-30 \mathrm{~cm}$ below the surface. Soil samples were collected at the surface from the A-horizon about $1-5 \mathrm{~cm}$ deep, original grain size was $<250 \mu \mathrm{m}$, and

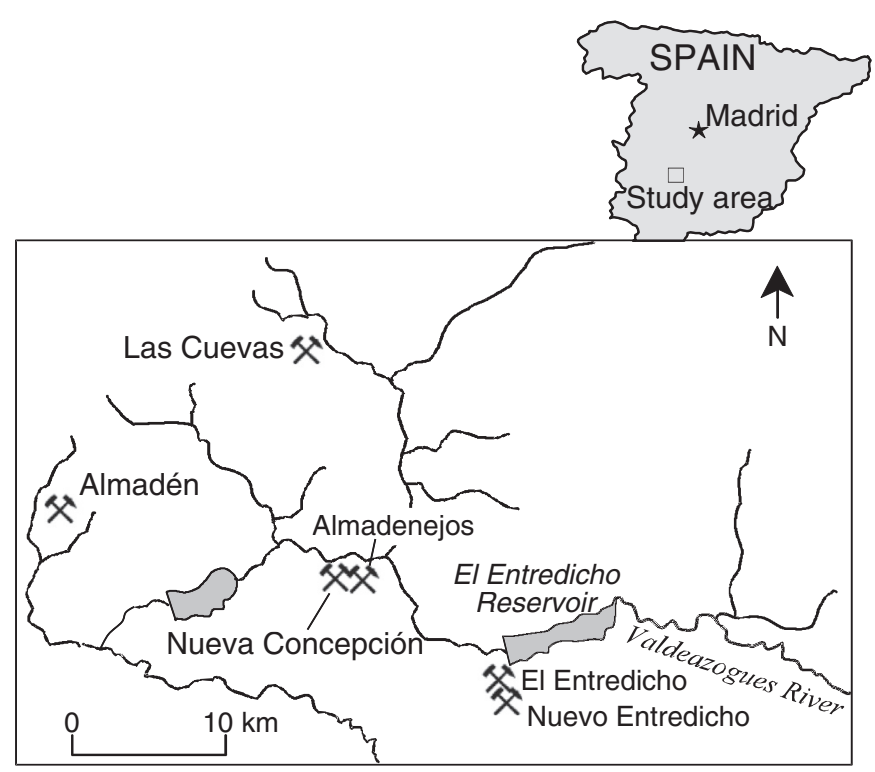

Fig. 1. Location of the mines studied. consisted dominantly of calcine ( 90\%), with lesser rock fragments ( $10 \%)$, and minor organic matter $(\sim 1-2 \%)$. All solid samples were hand ground with a mortar and pestle prior to chemical digestion and $\mathrm{Hg}$ isotopic analysis.

\subsection{MC-ICP-MS analysis}

Isotopic analysis of $\mathrm{Hg}$ was carried out at the U.S. Geological Survey (USGS) in Denver, Colorado, using a Nu Instruments HR® MC-ICP-MS. Cinnabar, $\mathrm{Hg}_{(\mathrm{L})}{ }_{(\mathrm{L})}$, calcine, schuetteite, and soil samples for $\mathrm{Hg}$ isotopic analysis were digested using concentrated $\mathrm{HNO}_{3}$ and $\mathrm{HCl}$ (9:1) following a method similar to that previously described (Foucher and Hintelmann, 2006). For samples with high organic matter such as soil, $1 \mathrm{~mL}$ of concentrated $\mathrm{H}_{2} \mathrm{O}_{2}$ was added slowly to assist in the digestion of organic material. The samples were heated on a hot plate at $80^{\circ} \mathrm{C}$ for $2-4 \mathrm{~h}$ until the formation of $\mathrm{NO}_{\mathrm{x}}$ gasses ceased and then the samples were diluted with $18 \mathrm{M} \Omega$ MilliQ water.

The Hg isotopic compositions were determined by a cold vapor (CV) generation method using a CETAC HGX-200 unit attached to the MCICP-MS. Argon carrier gas was introduced into the CV generation system at a flow rate of $55-65 \mathrm{~mL} / \mathrm{min}$ and a $3 \% \mathrm{w} / \mathrm{v}$ solution of $\mathrm{SnCl}_{2}$ was used as the reductant (Foucher and Hintelmann, 2006). The acidified $\mathrm{Hg}$ bearing solution was introduced at a flow rate of about $1.0 \mathrm{~mL} / \mathrm{min}$. Instrumental mass bias was monitored and corrected using the exponential law with the SRM NIST $997 \mathrm{Tl}$ isotope standard solution with a ${ }^{205} \mathrm{Tl}^{203} \mathrm{Tl}$ value of 2.3871 (Foucher and Hintelmann, 2006). The NIST $997 \mathrm{Tl}$ solution was introduced to the $\mathrm{Hg}^{0}$ sample flow for every sample just after the glass liquid separator via a desolvating nebulizer (Nu DSN 100). An Ar makeup gas flow of approximately $80 \mathrm{~mL} / \mathrm{min}$ was added prior to introduction into the plasma. The isotopic compositions of $\mathrm{Hg}$ were acquired using a single block of 30 cycles with a 10 second integration per cycle for a total data acquisition time of $5 \mathrm{~min}$ per sample. The sensitivity of the MC-ICP-MS for ${ }^{202} \mathrm{Hg}$ was $400-500 \mathrm{mV} / \mu \mathrm{g} / \mathrm{L}$ and data were collected using $\mathrm{Hg}$ solution concentrations for samples and standards of approximately $2-3 \mu \mathrm{g} / \mathrm{L}$. The SRM NIST $3133 \mathrm{Hg}$ standard was measured after every third unknown sample using a previously published method (Foucher and Hintelmann, 2006). The isotopes ${ }^{202} \mathrm{Hg},{ }^{201} \mathrm{Hg},{ }^{200} \mathrm{Hg},{ }^{199} \mathrm{Hg}$, and ${ }^{198} \mathrm{Hg}$ were measured simultaneously and $\mathrm{Hg}$ isotopic compositions are reported in standard delta notation as $\delta^{\mathrm{x}} \mathrm{Hg}$ in \% relative to the NIST 3133 standard (Blum and Bergquist, 2007). Mass bias-corrected values of $\delta^{\mathrm{x}} \mathrm{Hg}$ were used and calculated as shown, where $x=199,200,201$, or 202:

$\delta^{\mathrm{x}} \mathrm{Hg}=1000 \mathrm{x}\left(\left[\left({ }^{\mathrm{x}} \mathrm{Hg} /{ }^{198} \mathrm{Hg}\right)_{\text {sample }} /\left({ }^{\mathrm{x}} \mathrm{Hg} /{ }^{198} \mathrm{Hg}\right)_{\text {NIST 3133 }}\right]-1\right)$

The mean and $2 \sigma$ reproducibility for the UM-Almadén secondary reference material was $-0.54 \% \pm 0.10 \%$ o $(n=26)$ for $\delta^{202} \mathrm{Hg}$ and $-0.02 \pm 0.11 \%$ for $\Delta^{199} \mathrm{Hg}$ (Table 1 ). All data were assessed for mass independent fractionation (MIF) by calculating $\Delta^{199} \mathrm{Hg}$, $\Delta^{200} \mathrm{Hg}$, and $\Delta^{201} \mathrm{Hg}$ (Blum and Bergquist, 2007).

Triplicate analysis was carried out on three samples, which yielded $2 \sigma$ uncertainties of 0.08 to $0.11 \%$ of for $\delta^{202} \mathrm{Hg}$ and 0.01 to $0.12 \%$ o for $\Delta^{199} \mathrm{Hg}$ (Table 1). These uncertainties are similar to those reported for MC-ICP-MS analysis where $2 \sigma$ uncertainties for $\delta^{202} \mathrm{Hg}$ range from about 0.1 to $0.3 \%$ o (Bergquist and Blum, 2009; Estrade et al., 2009a; Sonke et al., 2010). The $2 \sigma$ uncertainties for $\delta^{202} \mathrm{Hg}$, as well as for the $2 \sigma$ uncertainties for the other $\mathrm{Hg}$ isotopic measurements, were considerably smaller than the range of data observed in this study.

\subsection{Retort experiments}

Roasting of cinnabar was carried out using a bench top retort in a controlled laboratory setting (Fig. 2). The objective of these experiments was to evaluate $\mathrm{Hg}$ isotopic fractionation of roasted Almadén cinnabar ore and the products generated calcine, $\mathrm{Hg}_{(\mathrm{L})}{ }^{(}$, and $\mathrm{Hg}^{0}(\mathrm{~g})$. 
Table 1

$\mathrm{Hg}$ isotopic data for samples collected in this study.

\begin{tabular}{|c|c|c|c|c|c|c|c|c|}
\hline Sample & Description & $\delta^{202} \mathrm{Hg}(\%)$ & $\delta^{201} \mathrm{Hg}(\%)$ & $\delta^{200} \mathrm{Hg}(\%)$ & $\delta^{199} \mathrm{Hg}(\%)$ & $\Delta^{201} \mathrm{Hg}(\%)$ & $\Delta^{200} \mathrm{Hg}(\%)$ & $\Delta^{199} \mathrm{Hg}(\% \circ)$ \\
\hline \multicolumn{9}{|l|}{ Almaden mine, cinnabar } \\
\hline MA-1 & Cinnabar in quartzite & 0.15 & -0.01 & 0.10 & -0.05 & -0.12 & 0.03 & -0.08 \\
\hline MA-2 & Cinnabar in quartzite & -0.56 & -0.50 & -0.34 & -0.25 & -0.08 & -0.06 & -0.11 \\
\hline MA-3 & Cinnabar in quartzite & -0.47 & -0.40 & -0.24 & -0.16 & -0.05 & 0.00 & -0.04 \\
\hline MA-4 & Cinnabar in quartzite & -0.92 & -0.72 & -0.55 & -0.35 & -0.03 & -0.09 & -0.12 \\
\hline MA-5 & Cinnabar in quartzite & -0.82 & -0.73 & -0.53 & -0.32 & -0.11 & -0.13 & -0.11 \\
\hline MA-6 & Cinnabar in breccia & -0.58 & -0.46 & -0.30 & -0.15 & -0.03 & -0.01 & 0.00 \\
\hline MA-7 & Vein cinnabar with goethite & -0.73 & -0.56 & -0.33 & -0.16 & -0.02 & 0.04 & 0.03 \\
\hline \multicolumn{9}{|l|}{ Other Almaden locations, cinnabar } \\
\hline EE-1 (El Entredicho) & Cinnabar in quartzite & -0.46 & -0.46 & -0.24 & -0.20 & -0.12 & -0.01 & -0.08 \\
\hline EE-2 (El Entredicho) & Cinnabar in quartzite & -0.50 & -0.37 & -0.24 & -0.16 & 0.01 & 0.01 & -0.04 \\
\hline EE-3 (El Entredicho) & Cinnabar in pyrite & -1.73 & -1.24 & -0.90 & -0.44 & -0.06 & -0.03 & -0.01 \\
\hline NE-1 (Nuevo Entredicho) & Cinnabar in breccia & -0.23 & -0.24 & -0.12 & -0.18 & -0.06 & 0.00 & -0.12 \\
\hline NE-2 (Nuevo Entredicho) & Cinnabar in breccia & -0.19 & -0.21 & -0.16 & -0.17 & -0.07 & -0.07 & -0.12 \\
\hline LC-1 (Las Cuevas) & Vein cinnabar in breccia & -0.10 & -0.07 & 0.00 & 0.02 & 0.01 & 0.05 & 0.04 \\
\hline LC-2 (Las Cuevas) & Cinnabar in breccia & -0.90 & -0.65 & -0.43 & -0.21 & 0.02 & 0.02 & 0.02 \\
\hline LC-3 (Las Cuevas) & $\begin{array}{l}\text { Cinnabar veins in quartzite, } \\
\text { minor } \mathrm{Hg}_{(\mathrm{L})}^{\mathrm{o}}\end{array}$ & -0.55 & -0.42 & -0.25 & -0.12 & -0.01 & 0.02 & 0.02 \\
\hline NC-1 (Nueva Concepcion) & Cinnabar in breccia & -0.08 & -0.14 & -0.05 & -0.14 & -0.08 & -0.01 & -0.12 \\
\hline NC-2 (Nueva Concepcion) & Cinnabar + pyrite $+\mathrm{Hg}^{\mathrm{O}}(\mathrm{L})$ in breccia & -0.06 & -0.03 & -0.05 & -0.08 & 0.01 & -0.02 & -0.06 \\
\hline \multicolumn{9}{|l|}{ Other Spanish districts } \\
\hline Usagre (Ossa Morena) & Cinnabar in limestone & -1.37 & -0.91 & -0.70 & -0.24 & 0.12 & -0.01 & 0.11 \\
\hline \multicolumn{9}{|l|}{ Elemental $\mathrm{Hg}^{\circ}(\mathrm{L})$} \\
\hline Hg-1 (El Entredicho) & Cinnabar + schuetteite $+<1 \% \mathrm{Hg}^{\mathrm{o}}(\mathrm{L})$ & 0.26 & 0.04 & 0.23 & 0.05 & -0.16 & 0.10 & -0.02 \\
\hline $\mathrm{Hg}-2$ (Almaden) & Native $\mathrm{Hg}_{(\mathrm{L})}^{\mathrm{o}}$ ore & -0.84 & -0.57 & -0.36 & -0.12 & 0.06 & 0.06 & 0.09 \\
\hline $\begin{array}{l}\mathrm{Hg}-3 \text { (blended-various locations) Native } \\
\mathrm{Hg}^{\mathrm{O}}{ }_{(\mathrm{L})} \text { ore }\end{array}$ & Native $\mathrm{Hg}_{(\mathrm{L})}^{\mathrm{O}}$ ore & -1.36 & -0.88 & -0.66 & -0.31 & 0.15 & 0.03 & 0.03 \\
\hline $\mathrm{Hg}-4$ (Las Cuevas) & Metallurgical $\mathrm{Hg}^{\mathrm{o}}(\mathrm{L})$ from retorting & -0.84 & -0.48 & -0.40 & -0.25 & 0.15 & 0.02 & -0.04 \\
\hline Hg-5 (Almaden from Hg flask) & Metallurgical $\mathrm{Hg}_{(\mathrm{L})}^{\mathrm{o}}$ from retorting & -0.67 & -0.49 & -0.34 & -0.20 & 0.01 & -0.01 & -0.03 \\
\hline Hg-6 (Chlor-alkali plant, Italy) & Metallurgical $\mathrm{Hg}_{(\mathrm{L})}^{\mathrm{o}}$ from retorting & -0.16 & -0.15 & -0.05 & -0.03 & -0.03 & 0.03 & 0.01 \\
\hline \multicolumn{9}{|l|}{ Schuetteite } \\
\hline MeA-1 (Almaden) & Schuetteite on retort brick & -0.70 & -0.58 & -0.32 & -0.15 & -0.05 & 0.04 & 0.03 \\
\hline MeA-2 (Almaden) & Schuetteite on retort wall & -1.40 & -0.97 & -0.66 & -0.29 & 0.08 & 0.05 & 0.07 \\
\hline AH-2 (Almadenejos) & Schuetteite on retort brick & 0.34 & 0.20 & 0.18 & 0.01 & -0.05 & 0.01 & -0.07 \\
\hline AH-3 (Almadenejos) & Schuetteite on retort brick & -0.31 & -0.13 & -0.10 & -0.17 & 0.10 & 0.05 & -0.09 \\
\hline SQ-1 (El Entredicho) & Schuetteite & 0.64 & 0.34 & 0.38 & 0.08 & -0.14 & 0.06 & -0.08 \\
\hline SEE-1 (El Entredicho) & Schuetteite on rock & -0.88 & -0.70 & -0.43 & -0.26 & -0.04 & 0.01 & -0.04 \\
\hline Sch-Syn (El Entredicho) & Schuetteite on rock & -0.24 & -0.30 & -0.21 & -0.17 & -0.12 & -0.09 & -0.11 \\
\hline \multicolumn{9}{|l|}{ Soil } \\
\hline AJ-703 (Almadenejos) & A-horizon soil containing calcine & 0.95 & 0.59 & 0.56 & 0.29 & -0.12 & 0.08 & 0.05 \\
\hline AJ-704 (Almadenejos) & A-horizon soil containing calcine & -0.05 & -0.12 & -0.05 & -0.11 & -0.08 & -0.03 & -0.10 \\
\hline \multicolumn{9}{|l|}{ Calcines } \\
\hline ES-51 & Calcine, minor cinnabar + Fe-oxide & -0.03 & -0.15 & -0.04 & -0.12 & -0.13 & -0.03 & -0.11 \\
\hline ES-52 & Calcine & 1.19 & 0.80 & 0.58 & 0.18 & -0.09 & -0.01 & -0.12 \\
\hline ES-53 & Calcine & 0.24 & 0.05 & 0.12 & 0.05 & -0.13 & 0.00 & -0.01 \\
\hline ES-54 & Calcine & 0.40 & 0.27 & 0.23 & 0.04 & -0.03 & 0.03 & -0.06 \\
\hline ES-55 & Calcine & 0.45 & 0.25 & 0.23 & 0.03 & -0.09 & 0.00 & -0.08 \\
\hline ES-56 & Calcine, minor cinnabar + Fe-oxide & 0.06 & 0.02 & 0.03 & -0.01 & -0.02 & 0.00 & -0.02 \\
\hline ES-57 & Calcine, minor cinnabar + Fe-oxide & 0.15 & 0.08 & 0.08 & 0.03 & -0.04 & 0.01 & -0.01 \\
\hline ES-58 & Calcine & 1.01 & 0.76 & 0.59 & 0.14 & 0.00 & 0.08 & -0.12 \\
\hline \multicolumn{9}{|l|}{ Triplicates } \\
\hline MA-5 & Cinnabar & -0.82 & -0.73 & -0.53 & -0.32 & -0.11 & -0.13 & -0.11 \\
\hline $2 \sigma$ & & 0.08 & 0.09 & 0.12 & 0.07 & 0.09 & 0.14 & 0.05 \\
\hline $\mathrm{NC}-1(\mathrm{n}=3)$ & Cinnabar in breccia & -0.08 & -0.14 & -0.05 & -0.14 & -0.08 & -0.01 & -0.12 \\
\hline $2 \sigma$ & & 0.11 & 0.06 & 0.02 & 0.10 & 0.04 & 0.04 & 0.12 \\
\hline SEE-1 $(\mathrm{n}=3)$ & Schuetteite on rock & -0.88 & -0.70 & -0.43 & -0.26 & -0.04 & 0.01 & -0.04 \\
\hline $2 \sigma$ & & 0.09 & 0.11 & 0.06 & 0.03 & 0.16 & 0.03 & 0.01 \\
\hline \multicolumn{9}{|l|}{ Almaden secondary standard } \\
\hline average $(n=26)$ & & -0.54 & -0.42 & -0.26 & -0.15 & -0.01 & 0.01 & -0.02 \\
\hline $2 \sigma$ & & 0.10 & 0.12 & 0.10 & 0.12 & 0.11 & 0.08 & 0.11 \\
\hline
\end{tabular}

About $1-5 \mathrm{~g}$ of hand ground cinnabar was placed in the retort chamber and heated to $600-700{ }^{\circ} \mathrm{C}$ using a Meeker burner until $\mathrm{Hg}_{(\mathrm{g})}^{0}$ was generated, which was then condensed to $\mathrm{Hg}^{0}{ }_{(\mathrm{L})}$ and collected in a water filled Teflon beaker trap. The $\mathrm{Hg}_{(\mathrm{L})}^{\mathrm{C}}$ was quickly decanted from the Teflon beaker water trap and stored in a clean glass vial with a Teflon lined lid. The $\mathrm{Hg}^{0}{ }_{(\mathrm{g})}$ generated prior to the condensation of $\mathrm{Hg}^{0}{ }_{(\mathrm{L})}$ was

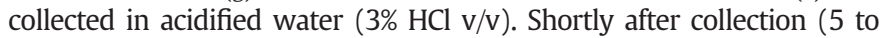

$10 \mathrm{~min}$ ) the $\mathrm{Hg}^{0}$ (g) solution was analyzed on the MC-ICP-MS. Additional techniques for collecting $\mathrm{Hg}^{0}{ }_{(\mathrm{g})}$ were tested during development of the retorting experiments including the use of a strong acid with a strong oxidant in an "impinger" (Rolison et al., 2013). However, when using an impinger on the retort, the system produced considerable hydrostatic pressure. This hydrostatic pressure was greater than the $\mathrm{Hg}_{(\mathrm{g})}^{\mathrm{O}}$ pressure in the retort, and as a result, minimal $\mathrm{Hg}_{(\mathrm{g})}^{0}$ was collected in the impinger. 


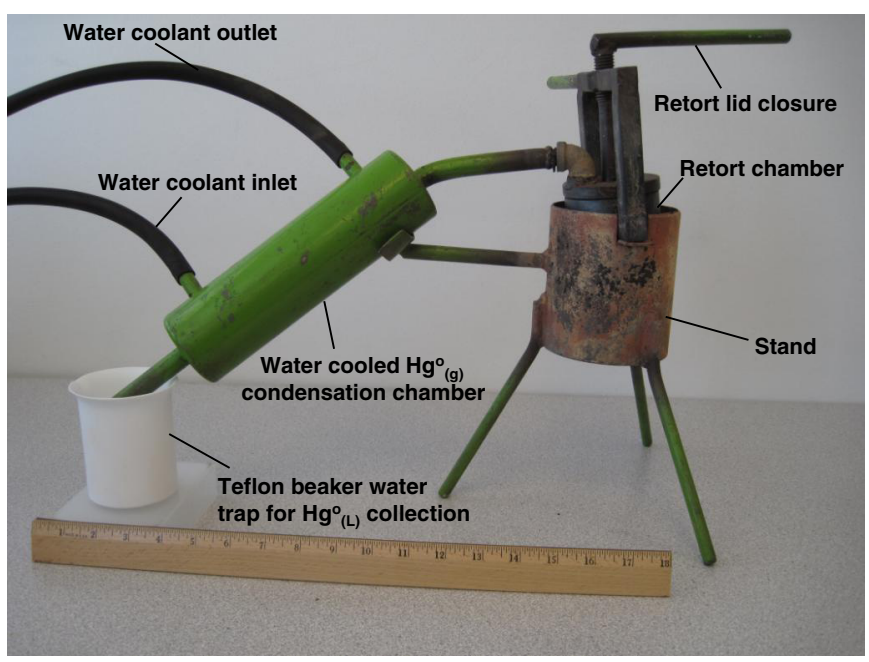

Fig. 2. Photo of retort used in laboratory cinnabar roasting experiments.

Previous studies incorporated either an $\mathrm{Ar} / \mathrm{O}_{2}$ gas flow through a tube furnace or air samples that were collected using a sampler that purged $\mathrm{Hg}^{0}{ }_{(\mathrm{g})}$ through an impinger (Rolison et al., 2013). It was not possible to modify the $\mathrm{Hg}$ retort to install a gas purging line, and the collection of $\mathrm{Hg}_{(\mathrm{g})}^{0}$ from the retort using an impinger was not consistent. Thus, the $\mathrm{Hg}$ isotopic data reported here for $\mathrm{Hg}^{0}(\mathrm{~g})$ were those using an $\mathrm{HCl}$ trap. The cinnabar, calcine, and $\mathrm{Hg}^{0}{ }_{(\mathrm{L})}$ were digested as described previously. The original cinnabar, calcine, $\mathrm{Hg}^{0}{ }_{(\mathrm{L})}$, and $\mathrm{Hg}^{0}{ }_{(\mathrm{g})}$ were all analyzed for $\mathrm{Hg}$ isotopic compositions using MC-ICP-MS.

\section{Results and discussion}

\subsection{Cinnabar}

To evaluate $\mathrm{Hg}$ isotopic variability in Almadén ore, 7 samples of cinnabar from Almadén and an additional 10 cinnabar samples from other mines and deposits within the Almadén district were analyzed (Table 1, Fig. 3). These Almadén mine cinnabar samples varied in $\delta^{202} \mathrm{Hg}$ from -0.92 to $0.15 \%$, with a mean of $-0.56 \%$ 。 $(\sigma=0.35 \%$, $\mathrm{n}=7$ ), which was similar in composition to that found in cinnabar collected from other deposits in the Almadén district that varied from
-1.73 to $-0.06 \%$, with a mean of $-0.48 \%$ o $(\sigma=0.51 \%$, $\mathrm{n}=10$ ). One exception was cinnabar collected from the El Entredicho deposit with a highly negative $\delta^{202} \mathrm{Hg}$ of $-1.73 \%$. This El Entredicho sample contained abundant pyrite $\left(\mathrm{FeS}_{2}\right)$ and is mineralogically dissimilar compared to the other Almadén district ore samples, which were dominantly cinnabar lacking pyrite (Table 1$)$. Another cinnabar sample with a negative $\mathrm{Hg}$ isotopic composition $\left(\delta^{202} \mathrm{Hg}=-1.37 \%\right.$ ) was collected from the Ossa Morena district $\left(38^{\circ} 21^{\prime} 24^{\prime \prime} \mathrm{N}, 6^{\circ} 11^{\prime} 8^{\prime \prime} \mathrm{W}\right)$ about $125 \mathrm{~km}$ WSW of Almadén (García-Sánchez et al., 2009). However, cinnabar in this deposit is in limestone host rock, which is also dissimilar to host rocks at Almadén that are dominantly quartzite (Table 1 ). The negative $\delta^{202} \mathrm{Hg}$ compositions of these two samples, and their different mineralogical compositions compared to typical Almadén ore, likely indicates that ore generated at these two localities was formed by processes different than that of other Almadén cinnabar, or the source of $\mathrm{Hg}$ was different than that of the remainder of the Almadén district. Almadén is the largest $\mathrm{Hg}$ district in the world with complex geological formations and cinnabar deposits found in varying wallrock (host rock) types, which were formed by varying processes (Hernandez et al., 1999; Higueras et al., 2003). For example, cinnabar in the Almadén and El Entredicho deposits are generally found disseminated in quartzite as well as in mineralized veins that constitute a stratabound-type deposit, whereas at the Las Cuevas deposit cinnabar is of an epigenetic origin and mostly found as vein fillings, replacements, and breccias (Higueras et al., 1999). The wide variation of $\delta^{202} \mathrm{Hg}$ in cinnabar throughout the Almadén district likely relates to various hydrothermal processes that generated cinnabar in these different settings. However, evaluation of different processes of cinnabar ore formation using $\mathrm{Hg}$ isotopes was not an objective here and is beyond the scope of this study.

In comparison, the range of $\mathrm{Hg}$ isotopic compositions of Almadén cinnabar was generally similar to that reported in the Wanshan mining district, China, in which $\delta^{202} \mathrm{Hg}$ ranged from -0.92 to $-0.56 \%$ o (mean $\delta^{202} \mathrm{Hg}=-0.75, \mathrm{n}=13$ ) (Yin et al., 2013). However, the $\delta^{202} \mathrm{Hg}$ compositions for various $\mathrm{Hg}$-bearing mineralized rocks and ore deposits in California and Nevada, USA, varied widely from -3.88 to $2.10 \%$, a variation of 5.98\% (Smith et al., 2005; Smith et al., 2008). A somewhat smaller variation in $\delta^{202} \mathrm{Hg}$ of -1.73 to $1.33 \%$, a range of $3.06 \%$, was found in cinnabar collected from numerous $\mathrm{Hg}$ mines and deposits worldwide (Hintelmann and Lu, 2003; Stetson, 2009). Variations in Hg isotopic compositions measured in $\mathrm{Hg}$-bearing mineralized rocks are likely due to variations in the $\mathrm{Hg}$ isotopic compositions of the source (host) rocks or isotopic $\mathrm{Hg}$ fractionation during ore formation, or both. Although

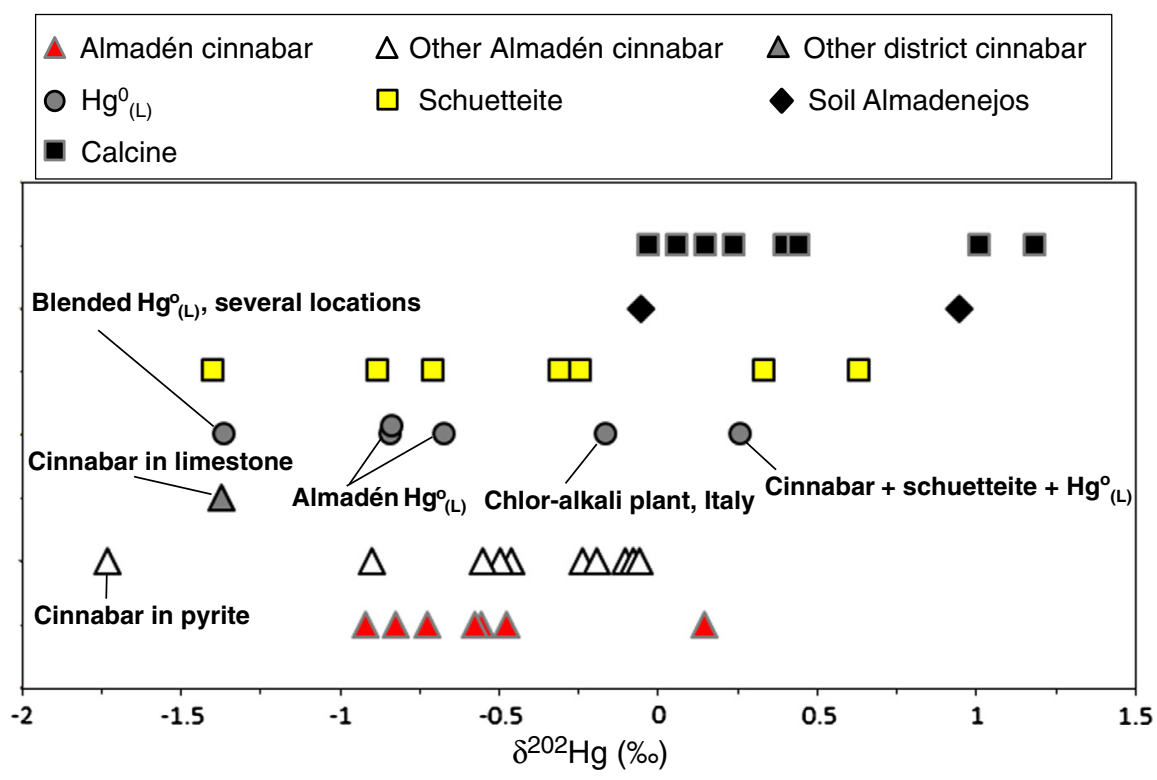

Fig. 3. Variation of $\delta^{202} \mathrm{Hg}$ in cinnabar, $\mathrm{Hg}_{(\mathrm{L})}{ }^{2}$, calcine, soil, and schuetteite in this study. 
previous studies have reported a wide variation in $\delta^{202} \mathrm{Hg}$ compositions for various $\mathrm{Hg}$ deposits worldwide (Hintelmann and Lu, 2003; Smith et al., 2005; Smith et al., 2008; Stetson et al., 2009), the Hg isotopic compositions of Almadén cinnabar samples shown here have an isotopically narrow variation of $\delta^{202} \mathrm{Hg}$ of $1.07 \%$ ( Fig. 1). No statistically significant MIF was found in any of the Almadén cinnabar samples (Fig. 4).

\subsection{Mine waste calcine and soil}

The $\delta^{202} \mathrm{Hg}$ for the calcine samples collected in the Almadén district show MDF, relative to the original cinnabar ore, as a result of the retorting process. The $\delta^{202} \mathrm{Hg}$ values for Almadén calcine ranged from $-0.03 \%$ o to $1.19 \%$, a variation of $1.22 \%$ (Table 1 , Fig. 1 ). The $\delta^{202} \mathrm{Hg}$ for Almadén calcine (mean $=0.43 \%, \sigma=0.44 \%, \mathrm{n}=8$ ) were isotopically heavier compared to the Almadén district cinnabar (mean $=-0.56 \%$, $\sigma=0.35 \%$ o, $\mathrm{n}=7$ ), an enrichment of $0.99 \%$. Other studies have reported such MDF of $\mathrm{Hg}$ isotopes due to retorting of cinnabar ore (Stetson et al., 2009; Gehrke et al., 2011; Yin et al., 2013). Stetson et al. (2009) reported MDF of as much as 3.24\% for $\delta^{202} \mathrm{Hg}$ in calcine compared to cinnabar, whereas MDF more similar to that reported here was found by Yin et al. (2013), who reported an enrichment of about $0.80 \%$, and Gehrke et al. (2011), who reported an increase of $0.43 \%$ for $\delta^{202} \mathrm{Hg}$ for calcine versus cinnabar. In addition, $\mathrm{MDF}$ of $\mathrm{Hg}$ isotopes was reported during smelting of $\mathrm{ZnS}$ ore, where

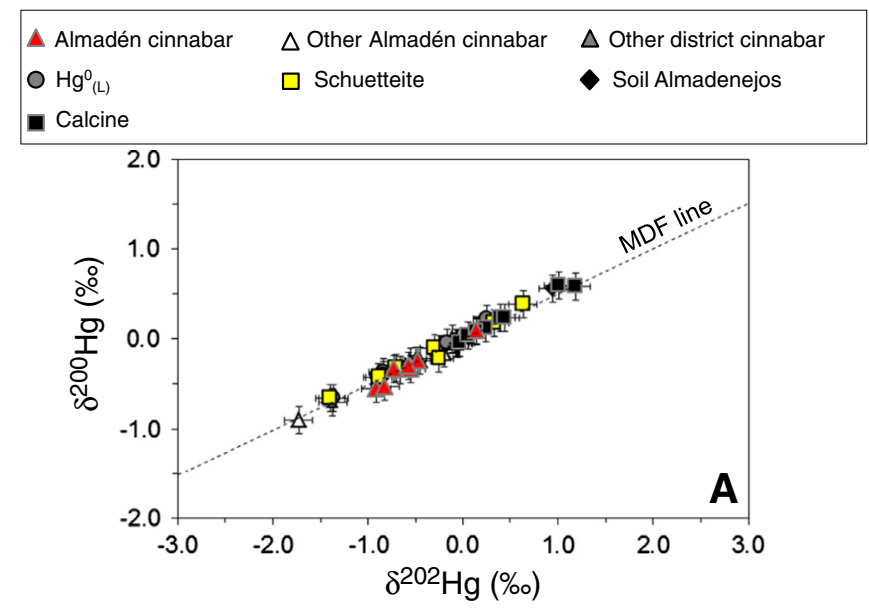

\begin{tabular}{|lll}
\hline Almadén cinnabar & $\Delta$ Other Almadén cinnabar & $\Delta$ Other district cinnabar \\
$\mathrm{Hg}_{(\mathrm{L})}$ & $\square$ Schuetteite & \\
$\square$ Calcine & &
\end{tabular}

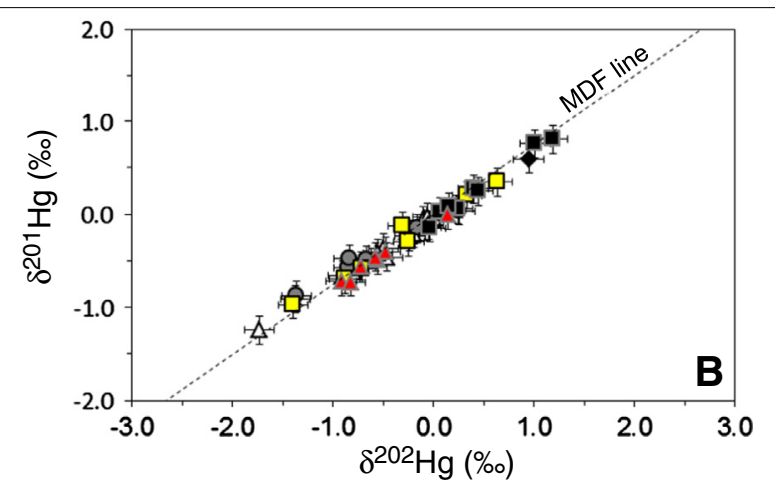

Fig. 4. Three isotope plots for cinnabar, $\mathrm{Hg}_{(\mathrm{L})}^{0}$, calcine, soil, and schuetteite collected in this study. Theoretical mass dependent fractionation (MDF) line shown for reference. Samples deviating from the MDF line outside of $2 \sigma$ error indicate mass independent fractionation (MIF). $\delta^{202} \mathrm{Hg}$ in $\mathrm{Zn}$ slag was shown to be about $0.41 \%$ o heavier than that in the original ore (Sonke et al., 2010). Generally, during retorting of cinnabar ore, $\mathrm{Hg}^{2+}$ in cinnabar is reduced to $\mathrm{Hg}^{\mathrm{O}}(\mathrm{g})$. The calcine formed during retorting is isotopically enriched in the heavier $\mathrm{Hg}$ isotopes relative to the original cinnabar and the volatilized $\mathrm{Hg}^{0}$ (g) (Stetson et al., 2009). However, as noted in previous studies, retorting is sometimes an incomplete process with not all cinnabar converted to $\mathrm{Hg}^{0}$ (Gray et al., 2004; Gosar et al., 2006; Stetson et al., 2009). Thus, some of the original cinnabar survives the retorting process and is present as microscopic grains in calcine or as fine-grained cinnabar encapsulated in gangue or rock fragments. Calcine samples with $\delta^{202} \mathrm{Hg}$ similar that of cinnabar ore contain significant residual cinnabar that was not completely altered during retorting (Stetson et al., 2009). The complexity and inefficiency of cinnabar retorting, make it difficult to identify the type of MDF process involved during retorting. Retorting does not follow a Rayleigh fractionation process because the original cinnabar ore is heterogeneous (composed of cinnabar, other $\mathrm{Hg}$ minerals as well as rock and gangue minerals), not homogeneous, as required by a Rayleigh process. In addition, other by-product $\mathrm{Hg}$ compounds are formed during retorting as well as $\mathrm{Hg}(\mathrm{g})$, and the process of cinnabar retorting is not complete or completely efficient. As noted previously, several other studies have reported MDF of $\mathrm{Hg}$ isotopes during cinnabar ore roasting (Stetson et al., 2009; Gehrke et al., 2011; Yin et al., 2013), producing isotopically enriched $\mathrm{Hg}$ isotopes in calcine relative to the original cinnabar ore. Other theoretical calculations or experimental studies have reported that MDF of $\mathrm{Hg}$ isotopes is related to processes such as equilibrium or kinetic effects (Young et al., 2002; Schauble, 2007; Estrade et al., 2009b; Ghosh et al., 2013). Because there is not one reactant and one product during cinnabar ore retorting, it is not possible to evaluate these MDF processes based on the $\mathrm{Hg}$ isotopic data obtained in this study. However, in this study, it is clear that MDF of $\mathrm{Hg}$ isotopes is related to sublimation of cinnabar ore during retorting that was carried out at temperatures $>600{ }^{\circ} \mathrm{C}$, similar to that reported in other studies (Stetson et al., 2009; Gehrke et al., 2011; Yin et al., 2013).

Two soil samples collected from the Almadenejos site were analyzed (Table 1). Almadenejos was a site of active cinnabar retorting in the 19th century and considerable mine-waste calcine was discarded in this area and remains today (Gray et al., 2004; Martínez-Coronado et al., 2011). These two soil samples were collected from the near surface A-horizon and composed dominantly of calcine with minor organic matter. The soil samples contained $\delta^{202} \mathrm{Hg}$ that varied from -0.05 to $0.93 \%$, similar to the range of $\delta^{202} \mathrm{Hg}$ observed for the Almadén calcine samples (Fig. 3). Also similar to the results for the calcine, these soil samples indicate MDF as a result of cinnabar retorting. No statistically significant MIF was found in any of the calcine or soil samples analyzed in this study (Fig. 2).

\subsection{Elemental $\mathrm{Hg}$}

Six $\mathrm{Hg}^{0}(\mathrm{~L})$ samples were collected from various locations and consisted of three samples of native ore $\mathrm{Hg}^{0}(\mathrm{~L})$, and three metallurgical $\mathrm{Hg}^{0}$ (L) samples produced from retorting of $\mathrm{Hg}$ ore (Table 1, Fig. 3). The $\delta^{202} \mathrm{Hg}$ for three $\mathrm{Hg}^{0}{ }_{(\mathrm{L})}$ samples from the Almadén district $(\mathrm{Hg}-2$, native ore, and $\mathrm{Hg}-4$ and $\mathrm{Hg}-5$, metallurgical $\mathrm{Hg}_{(\mathrm{L})}^{\mathrm{O}}$ ) varied within a narrow range -0.84 to $-0.67 \%$ o (mean $=-0.78 \%$ o, $\sigma=0.10 \%$ ). All three of the Almadén district $\mathrm{Hg}^{\mathrm{O}}(\mathrm{L})$ samples were similar in isotopic composition to Almadén district cinnabar samples with the lowest $\delta^{202} \mathrm{Hg}$ (Table 1, MA4, MA5, and MA7, -0.72 to $-0.92 \%$ ). The $\delta^{202} \mathrm{Hg}$ mean of the three Almadén district $\mathrm{Hg}^{\mathrm{O}}$ (L) samples $(-0.78 \%$ ) was not statistically different compared to the $\delta^{202} \mathrm{Hg}$ mean of the Almadén cinnabar samples ( $-0.56 \%, \sigma=0.35 \%, \mathrm{n}=7$ ) and these data analytically overlap. However, there were only three samples of Almadén district $\mathrm{Hg}^{0}{ }_{(\mathrm{L})}$ available for $\mathrm{Hg}$ isotopic analysis, and in addition, the original cinnabar, which was retorted and produced such $\mathrm{Hg}_{(\mathrm{L})}{ }_{(\mathrm{L})}$, is not known with certainty. Thus, it is difficult to evaluate any $\mathrm{Hg}$ isotopic fractionation of $\mathrm{Hg}_{(\mathrm{L})}^{\mathrm{O}}$ based on these few samples. 
Table 2

$\mathrm{Hg}$ isotopic data for samples obtained during cinnabar retorting in this study

\begin{tabular}{|c|c|c|c|c|c|c|c|}
\hline Sample & $\delta^{202} \mathrm{Hg}(\%)$ & $\delta^{201} \mathrm{Hg}(\%)$ & $\delta^{200} \mathrm{Hg}(\%)$ & $\delta^{199} \mathrm{Hg}(\%)$ & $\Delta^{201} \mathrm{Hg}(\%)$ & $\Delta^{200} \mathrm{Hg}(\%)$ & $\Delta^{199} \mathrm{Hg}(\%)$ \\
\hline Almaden cinnabar-8 & -0.24 & -0.28 & -0.12 & -0.10 & -0.10 & 0.00 & -0.04 \\
\hline $8-\mathrm{Hg}^{0}(\mathrm{~L})$ & 0.18 & 0.05 & 0.08 & 0.00 & -0.08 & -0.01 & -0.05 \\
\hline 8-calcine & 1.50 & 0.98 & 0.72 & 0.22 & -0.15 & -0.03 & -0.16 \\
\hline $8-\mathrm{Hg}^{0}(\mathrm{~g})$ & -1.40 & -1.01 & -0.71 & -0.32 & 0.04 & 0.00 & 0.04 \\
\hline Almaden cinnabar-9 & -0.43 & -0.16 & -0.09 & -0.08 & 0.16 & 0.12 & 0.03 \\
\hline $9-\mathrm{Hg}^{\mathrm{O}}(\mathrm{L})$ & 0.04 & -0.03 & 0.12 & 0.08 & -0.06 & 0.10 & 0.07 \\
\hline 9-calcine & 1.47 & 0.98 & 0.70 & 0.30 & -0.12 & -0.04 & -0.07 \\
\hline $9-\mathrm{Hg}^{0}(\mathrm{~g})$ & -1.33 & -1.04 & -0.81 & -0.49 & -0.04 & -0.14 & -0.15 \\
\hline Almaden cinnabar-12 & -0.41 & -0.35 & -0.20 & -0.09 & -0.04 & 0.01 & 0.01 \\
\hline $12-\mathrm{Hg}^{0}(\mathrm{~L})$ & 0.26 & 0.08 & 0.11 & -0.02 & -0.12 & -0.02 & -0.09 \\
\hline 12-calcine & 0.70 & 0.44 & 0.44 & 0.28 & -0.09 & 0.09 & 0.10 \\
\hline $12-\mathrm{Hg}^{0}(\mathrm{~g})$ & -0.71 & -0.44 & -0.21 & -0.04 & 0.09 & 0.15 & 0.14 \\
\hline
\end{tabular}

Two $\mathrm{Hg}^{0}(\mathrm{~L})$ samples were enriched in heavier $\mathrm{Hg}$ isotopes compared that of Almadén $\mathrm{Hg}^{\mathrm{O}}(\mathrm{L})$ including (1) sample $\mathrm{Hg}$-6, which was metallurgical $\mathrm{Hg}^{0}{ }_{(\mathrm{L})}$ collected from a chlor-alkali plant in Italy $\left(\delta^{202} \mathrm{Hg}=-0.16 \%\right.$ 。) and $(2) \mathrm{Hg}-1\left(\delta^{202} \mathrm{Hg}=0.26 \%\right.$ o), which contained mostly cinnabar and schuetteite, with only minor native ore $\mathrm{Hg}_{(\mathrm{L})}^{0}$ (Table 1, Fig. 3). A native ore $\mathrm{Hg}^{\mathrm{O}}{ }_{(\mathrm{L})}$ sample (Hg-3, Table 1$)$ was found to be the isotopically lightest of the $\mathrm{Hg}^{0}{ }_{(\mathrm{L})}$ samples $\left(\delta^{202} \mathrm{Hg}=-1.36 \%\right.$ ), which was a blend of native ore $\mathrm{Hg}_{(\mathrm{L})}^{\mathrm{C}}$ from the Almadén, El Entredicho, and Las Cuevas mines. Sample $\mathrm{Hg}-3$ was likely isotopically lighter in $\mathrm{Hg}$ isotopes because cinnabar from El Entredicho was found to have the lightest $\delta^{202} \mathrm{Hg}$ in this study (Table 1, Fig. 3, $-1.73 \%$ ). Previous studies have indicated that retorting of cinnabar produces $\mathrm{Hg}^{0}(\mathrm{~L})$ that is isotopically lighter in $\mathrm{Hg}$ isotopes as a result of MDF (Stetson et al., 2009; Yin et al., 2013). However, in this study, it was not possible to evaluate MDF in the $\mathrm{Hg}^{0}{ }_{(\mathrm{L})}$ analyzed here because the $\mathrm{Hg}$ isotopic composition of the original ore(s) that produced the metallurgic $\mathrm{Hg}^{0}{ }_{(\mathrm{L})}$ is unknown. In this study, $\mathrm{Hg}$ isotopic MDF during cinnabar retorting was evaluated in the laboratory retorting experiments as discussed in Section 3.5. ${\mathrm{The} \mathrm{Hg}^{\mathrm{O}}}_{(\mathrm{L})}$ samples in this study did not show any statistically significant MIF (Table 1 , Fig. 4A-C).

\subsection{Schuetteite}

The $\delta^{202} \mathrm{Hg}$ values for Almadén district schuetteite samples varied widely from $-1.40 \%$ o to $0.64 \%$, a variation of $2.04 \%$ (Table 1 , Fig. 3 ). The $\delta^{202} \mathrm{Hg}$ values measured for schuetteite were similar to, but more variable than, the range of composition found for Almadén district cinnabar in this study (Fig. 3). Schuetteite in the Almadén district is found only locally in calcine at El Entredicho, and in some instances, inside retort facilities at Almadén and Almadenejos on old retort bricks or on walls within areas where $\mathrm{Hg}^{0}(\mathrm{~L})$ has been stored. Schuetteite constitutes $\ll 1 \%$ of the total $\mathrm{Hg}$ in calcine. Because schuetteite was collected from retort bricks and walls, it was presumed that such schuetteite likely formed due to precipitation or oxidation of $\mathrm{Hg}^{0}(\mathrm{~g})$ in or around such facilities. However, due to the wide range of $\delta^{202} \mathrm{Hg}$ values for schuetteite, it is difficult to relate the formation of this compound to a specific source or formation process. Similar to the other samples in this study, schuetteite did not show any statistically significant MIF (Table 1, Fig. 4A-C).

\subsection{Cinnabar retorting laboratory experiments}

Several cinnabar retorting experiments were carried out using a small, portable retort (Fig. 2) in a controlled laboratory setting. In these experiments, the original cinnabar ore, and the generated calcine, $\mathrm{Hg}^{0}{ }_{(\mathrm{L})}$, and $\mathrm{Hg}^{0}{ }_{(\mathrm{g})}$ were collected and measured for $\mathrm{Hg}$ isotopic compositions to evaluate isotopic fractionation directly related to cinnabar ore retorting. Three separate aliquots of hand ground Almadén cinnabar were retorted in these experiments with $\delta^{202} \mathrm{Hg}$ that varied from -0.43 to $-0.24 \%$ (mean of $-0.36 \%$ o, $\sigma=0.10 \%$ ) (Table 2 ). The $\delta^{202} \mathrm{Hg}$ for calcine generated during these experiments varied from 0.70 to $1.50 \%$ (mean of $1.22 \%, \sigma=0.45 \%, \mathrm{n}=3$ ) and was similar to, but heavier than, the $\delta^{202} \mathrm{Hg}$ ( -0.03 to $1.19 \%$, mean $=0.43 \%, \sigma=0.44 \%$, $\mathrm{n}=7$ ) for calcine collected from Almadén (Table 1). The retort generated calcines were enriched in the heavier $\mathrm{Hg}$ isotopes compared to cinnabar ore indicating MDF (Fig. 5). The $\delta^{202} \mathrm{Hg}$ for $\mathrm{Hg}^{0}{ }_{(\mathrm{L})}$ ranged from 0.04 to $0.26 \%$ (mean of $0.16 \%, \sigma=0.11 \%, \mathrm{n}=3$ ) which was isotopically heavy relative to cinnabar ore. This result was unexpected as the $\delta^{202} \mathrm{Hg}$ for the three previously mentioned Almadén $\mathrm{Hg}^{0}(\mathrm{~L})$ samples were
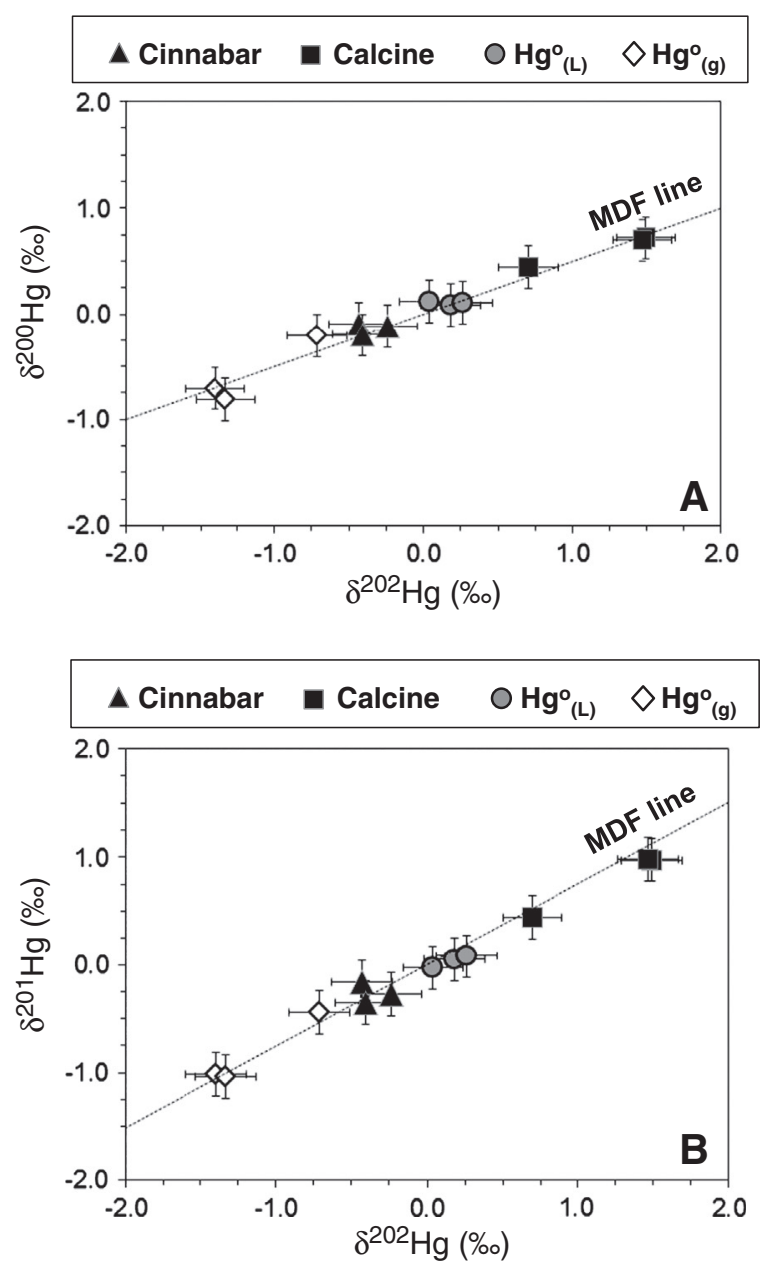

Fig. 5. Three isotope plots for cinnabar, $\mathrm{Hg}^{0}(\mathrm{~L})$, and calcine samples from the retorting experiments. Theoretical mass dependent fractionation (MDF) line shown for reference. Samples deviating from the MDF line outside of $2 \sigma$ error indicate mass independent fractionation (MIF) 
isotopically lighter than the mean $\delta^{202} \mathrm{Hg}$ of Almadén cinnabar (Table 1, Fig. 3). During retorting experiments, the generation of $\mathrm{Hg}^{0}{ }_{(\mathrm{L})}$ was slow and varied considerably in the time it took to condense, generally several minutes after exceeding the temperature of the sublimation point of cinnabar $\left(584^{\circ} \mathrm{C}\right)$. It is possible that the $\mathrm{Hg}_{(\mathrm{L})}^{0}$ initially condensed during retorting collected in the upper arm of the retort chamber (Fig. 2) and continued to isotopically fractionate as isotopically lighter $\mathrm{Hg}_{(\mathrm{g})}^{\mathrm{O}}$ was produced, eventually forming $\mathrm{Hg}^{0}$ (L) that was isotopically heavier than the original cinnabar ore. The collection of $\mathrm{Hg}^{0}$ (g) was difficult in this system. It is possible that some $\mathrm{Hg}_{(\mathrm{g})}^{\mathrm{O}}$ escaped during the retorting experiments and did not condense to $\mathrm{Hg}^{\mathrm{O}}(\mathrm{L})$. Multiple techniques were attempted to capture the generated $\mathrm{Hg}^{0}(\mathrm{~g})$, however, allowing the generated $\mathrm{Hg}_{(\mathrm{g})}^{\mathrm{O}}$ to bubble up through an acidic water trap was found to be the best technique (as discussed in Section 2.3). Analysis of the acidic water trap containing the $\mathrm{Hg}^{\mathrm{O}}{ }_{(\mathrm{g})}$ resulted in a $\delta^{202} \mathrm{Hg}$ variation from -1.40 to $-0.71 \%$ o (mean of $-1.15 \%$, $\sigma=0.38 \%$, $n=3$ ) (Table 2). The generated $\mathrm{Hg}^{\mathrm{O}}$ (g) was considerably lighter in $\mathrm{Hg}$ isotopes relative to the original cinnabar ore. These results are preliminary as additional experiments are required to determine a comprehensive method for the recovery of $\mathrm{Hg}^{0}(\mathrm{~g})$ generated in retorting experiments. However, mass balance was evaluated during these retorting experiments using the following equation:

$$
\begin{aligned}
& \left(\mathrm{f}_{\text {(calcine) })} * \delta^{202} \mathrm{Hg}_{(\text {calcine })}\right)+\left(\mathrm{f}_{(\mathrm{Hg}(\mathrm{L}))} * \delta^{202} \operatorname{Hg}_{(\mathrm{Hg}(\mathrm{L}))}\right)+\left(\mathrm{f}_{(\mathrm{Hg}(\mathrm{g}))} * \delta^{202} \operatorname{Hg}_{(\operatorname{Hg}(\mathrm{g}))}\right) \\
& \quad=\delta^{202} \mathrm{Hg}_{\text {(ore })}
\end{aligned}
$$

where: $f_{(x)}$ is the weight fraction of the cinnabar ore reactant or products, e.g., calcine, $\mathrm{Hg}_{(\mathrm{L})}{ }^{\mathrm{C}}$, and $\mathrm{Hg}^{0}{ }_{(\mathrm{g})}$. These calculations indicated that the retorting experiments produced a $\delta^{202} \mathrm{Hg}$ (ore) (mean $=-0.31 \% \circ \pm 0.11 \%$ ) that was within analytical error of the original cinnabar ore $\delta^{202} \mathrm{Hg}$ (ore) $(-$ mean $=-0.36 \% \pm 0.11 \%$ ).

The negative $\delta^{202} \mathrm{Hg}\left(-1.40\right.$ to $-0.70 \%$ ) for $\mathrm{Hg}^{0}{ }_{(\mathrm{g})}$ collected during the retort experiments (Table 2, Fig. 5) were within the range of those previously reported in soil, peat, moss, and lichen $\left(\delta^{202} \mathrm{Hg} \sim-3.0\right.$ to $0.0 \%$ ), which have been interpreted to represent atmospheric $\mathrm{Hg}$ isotopic compositions (Biswas et al., 2008; Ghosh et al., 2008; Bergquist and Blum, 2009; Carignan et al., 2009; Sherman et al., 2010; Sonke et al., 2010; Das et al., 2013; Rolison et al., 2013). In addition, the negative $\delta^{202} \mathrm{Hg}$ shown here for retorting derived $\mathrm{Hg}_{(\mathrm{g})}^{0}$ were also similar to that reported for atmospheric $\mathrm{Hg}_{(\mathrm{g})}^{0}\left(\delta^{202} \mathrm{Hg}=-1.73 \%\right.$ ) and $\mathrm{Hg}$ condensates emitted from volcanic fumaroles $\left(\delta^{202} \mathrm{Hg}=-1.09\right.$ to $-0.15 \%$ ) (Zambardi et al., 2009) as well as $\delta^{202} \mathrm{Hg}(-0.39$ to $-0.14 \%$ o) reported in flue gas emissions from coal-fired power plants (Sun et al., 2013). Retorting of cinnabar ore clearly emits $\mathrm{Hg}_{(\mathrm{g})}^{0}$ to the atmosphere. Furthermore, as the isotopic $\mathrm{Hg}$ data determined here for $\mathrm{Hg}^{0}$ (g) are similar to that previously reported for atmospheric $\mathrm{Hg}$, it is likely that $\mathrm{Hg}$ emissions from cinnabar retorting from large deposits such as Almadén have contributed $\mathrm{Hg}_{(\mathrm{g})}^{\mathrm{O}}$ to the overall global budget of atmospheric Hg. Although concentrations of $\mathrm{Hg}$ in $\mathrm{Hg}^{0}{ }_{(\mathrm{g})}$ emissions from mines are locally elevated, some studies have suggested that $\mathrm{Hg}$ emissions from mined areas are a significant, but a smaller source of $\mathrm{Hg}$ to the atmosphere compared to larger $\mathrm{Hg}$ emissions such as burning of fossil fuels, evaporation from oceans, and other land sources (Mason et al., 1994; Porcella, 1994; Ferrara et al., 1998; Fitzgerald et al., 1998; Lamborg et al., 2002; Higueras et al., 2013; Kocman et al., 2013). For example, Ferrara et al. (1998) used atmospheric measurements of $\mathrm{Hg}$ from several point sources in the Almadén area to estimate that the total $\mathrm{Hg}$ flux from the Almadén district represented about $0.1 \%$ of the global anthropogenic emission rate. In addition, other studies have suggested that $\mathrm{Hg}$ emissions from all mined areas contributes about $1-2 \%$ of the total atmospheric global $\mathrm{Hg}$ budget (Hudson et al., 1995; Kocman et al., 2013).

In this study, $\mathrm{Hg}$ isotopic MDF without MIF was found in $\mathrm{Hg}_{(\mathrm{g})}{ }_{(\mathrm{g})}$ and $\mathrm{Hg}^{\mathrm{O}}(\mathrm{L})$, whereas various studies have reported $\mathrm{Hg}$ isotopic MIF in samples representative of atmospheric $\mathrm{Hg}$ deposition (Bergquist and Blum, 2009; Carignan et al., 2009; Sherman et al., 2010; Sonke et al., 2010; Das et al.,
2013). As mentioned previously, the negative $\delta^{202} \mathrm{Hg}$ reported here for $\mathrm{Hg}^{0}$ (g) generated during the retorting experiments is similar to the negative $\delta^{202} \mathrm{Hg}$ reported for atmospheric $\mathrm{Hg}_{(\mathrm{g})}^{0}$, but MIF was not found in the retort derived $\mathrm{Hg}^{0}{ }_{(\mathrm{g})}$. Two possible explanations for the lack of MIF in $\mathrm{Hg}^{0}{ }_{(\mathrm{g})}$ generated during industrial cinnabar retorting are 1) when such $\mathrm{Hg}_{(\mathrm{g})}^{0}$ enters the atmosphere, the photochemical cycle further fractionates $\mathrm{Hg}$, resulting in MIF, and 2) industrial derived $\mathrm{Hg}_{(\mathrm{g})}^{\mathrm{C}}$ is a minor, insignificant contribution of $\mathrm{Hg}$ to the overall global budget of atmospheric $\mathrm{Hg}$.

\section{Conclusions}

Samples of Almadén cinnabar varied in $\delta^{202} \mathrm{Hg}$ from -0.92 to $0.15 \%$ 。 (mean $=-0.56 \%, \sigma=0.35 \%$ o, $\mathrm{n}=7$ ), whereas $\delta^{202} \mathrm{Hg}$ values for Almadén calcine ranged from $-0.03 \%$ 。 to $1.19 \%$, (mean $=0.43 \%$, $\sigma=0.44 \%, \mathrm{n}=8$ ). Thus, these $\delta^{202} \mathrm{Hg}$ data show an average enrichment of $0.99 \%$ between cinnabar and calcine, indicating $\mathrm{Hg}$ isotopic MDF during cinnabar ore retorting at Almadén. Samples of Almadén district $\mathrm{Hg}^{0}{ }_{(\mathrm{L})}$ were similar in composition to Almadén cinnabar samples with the lowest $\delta^{202} \mathrm{Hg}(-0.92 \%)$, but the $\delta^{202} \mathrm{Hg}$ mean of the three Almadén $\mathrm{Hg}^{0}{ }_{(\mathrm{L})}$ samples $(-0.78 \%$ o, $\sigma=0.10 \%$ o) was analytically indistinguishable from the $\delta^{202} \mathrm{Hg}$ for Almadén cinnabar samples $(-0.56 \%$, $\sigma=0.35 \%, \mathrm{n}=7)$. Schuetteite is common in the Almadén district and its formation has been presumed to be due to precipitation or oxidation of $\mathrm{Hg}_{(\mathrm{g})}^{\mathrm{C}}$ because it is common in or around facilities where $\mathrm{Hg}^{0}(\mathrm{~L})$ has been stored. However, the $\delta^{202} \mathrm{Hg}$ values for the schuetteite samples varied from -1.40 to $0.64 \%$, a variation of $2.04 \%$, thus, it was not possible to relate formation schuetteite to a specific source using $\mathrm{Hg}$ isotopic compositions.

Data shown here are the first reported for laboratory roasting of cinnabar ore using a small, experimental retort to investigate $\mathrm{Hg}$ isotopic fractionation during retorting. The $\mathrm{Hg}$ isotopic data confirmed MDF as the $\delta^{202} \mathrm{Hg}$ for calcines ( $m e a n=1.22 \%, \sigma=0.45 \%, \mathrm{n}=3$ ) formed during the experiments was found to be considerably heavier in $\delta^{202} \mathrm{Hg}$ compared to that of the original cinnabar ore (mean $=-0.36 \%, \sigma=$ $0.10 \%, \mathrm{n}=3$ ). Conversely, the $\delta^{202} \mathrm{Hg}$ for $\mathrm{Hg}_{(\mathrm{L})}^{0}$ generated during the retorting experiments ranged from 0.04 to $0.26 \%$ o (mean $=0.16 \%$, $\sigma=0.11 \%$, $\mathrm{n}=3$ ), which was isotopically enriched in heavy $\mathrm{Hg}$ isotopes relative to the original cinnabar ore. The $\delta^{202} \mathrm{Hg}$ for $\mathrm{Hg}^{\mathrm{0}}(\mathrm{g})$ generated during retorting varied from -1.40 to $-0.71 \%$ ( mean $-1.15 \%$, $\sigma=0.38 \%$, $n=3$ ) was found to be isotopically lighter compared to the retorted cinnabar ore. In effect, when cinnabar ore is roasted, the resultant calcines formed are isotopically heavier, whereas the $\mathrm{Hg}^{0}(\mathrm{~g})$ generated is considerably isotopically lighter in $\mathrm{Hg}$ isotopes. Using a simple mass balance calculation, the retorting experiments produced a $\delta^{202} \mathrm{Hg}$ (ore) (mean $=-0.31 \% \pm 0.11 \%$ ) that was within analytical error of the of the original cinnabar ore $\delta^{202} \mathrm{Hg}$ (ore) (mean $=-0.36 \%$ 。 $\pm 0.11 \%$ o). The $\mathrm{Hg}$ isotope data determined here for $\mathrm{Hg}^{0}{ }_{(\mathrm{g})}$ were similar to that previously reported for atmospheric $\mathrm{Hg}$ worldwide.

\section{Acknowledgments}

This study was funded by the U.S. Geological Survey (USGS, Mineral Resources Program), and the Spanish Ministry of Science (Project CTM2012-33918). We thank Dr. Fernando Palero for providing some of the samples analyzed in this study from his personal mineral collection. We thank Danny Rutherford for his assistance with the Hg isotopic analysis of samples in the USGS MC-ICP-MS laboratory. The bench top retort used in the experiments was provided by Dra. Felicia Contreras from the Venezuelan Ministry of the Environment. We thank the reviewers from the USGS and those for Chemical Geology for the constructive comments that helped to improve this paper. Any use of trade, product, or firm names is for descriptive purposes only and does not imply endorsement by the U.S. Government. 


\section{References}

Bailey, E.A., Gray, J.E., Theodorakos, P.M., 2002. Mercury in vegetation and soils at abandoned mercury mines in southwestern Alaska, USA. Geochem. Explor. Environ. Anal. 2 (3), 275-285.

Bergquist, B.A., Blum, J.D., 2009. The odds and evens of mercury isotopes: applications of mass-dependent and mass-independent isotope fractionation. Elements 5 (6), 353-357.

Bernaus, A., Gaona, X., Esbrí, J.M., Higueras, P., Falkenberg, G., Valiente, M., 2006. Microprobe techniques for speciation analysis and geochemical characterization of mine environments: the mercury district of Almadén in Spain. Environ. Sci. Technol. 40 4090-4095.

Berzas Nevado, J.J., Garcia Bermejo, L.F., Rodriguez Martin-Doimeadios, R.C., 2003. Distribution of mercury in the aquatic environment at Almadén, Spain. Environ. Pollut. $122,261-271$

Biswas, A., Blum, J.D., Bergquist, B.A., Keeler, G.J., Xie, Z., 2008. Natural mercury isotope variation in coal deposits and organic soils. Environ. Sci. Technol. 42, 8303-8309.

Blum, J.D., Bergquist, B.A., 2007. Reporting of variations in the natural isotopic composition of mercury. Anal. Bioanal. Chem. 388 (2), 353-359.

Carignan, J., Estrade, N., Sonke, J.E., Donard, O.F.X., 2009. Odd isotope deficits in atmospheric Hg measured in lichens. Environ. Sci. Technol. 43, 5660-5664.

Das, R., Bizimis, M., Wilson, A.M., 2013. Tracing mercury seawater vs. atmospheric inputs in a pristine SE USA salt marsh system: mercury isotope evidence. Chem. Geol. 336, 50-61.

Esbrí, J.M., Bernaus, A., Ávila, M., Kocman, D., García-Noguero, E.M., Guerrero, B., Gaona, X., Álvarez, R., Perez-Gonzalez, G., Valiente, M., Higueras, P., Horvat, M., Loredo, J., 2010. XANES speciation of mercury in three mining districts - Almadén, Asturias (Spain), Idria (Slovenia). J. Synchrotron Radiat. 17, 179-186.

Estrade, N., Carignan, J., Sonke, J.E., Donard, O.F.X., 2009a. Measuring Hg isotopes in biogeo-environmental reference materials. Geostand. Geoanal. Res. 34, 79-83.

Estrade, N., Carignan, J., Sonke, J.E., Donard, O.F.X., 2009b. Mercury isotope fractionation during liquid-vapor evaporation experiments. Geochim. Cosmochim. Acta 73, 2693-2711

Feng, X., Qiu, G., 2008. Mercury pollution in Guizhou, Southwestern China - an overview. Sci. Total. Environ. 400, 227-237.

Ferrara, R., Maserti, B.E., Andersson, M., Edner, H., Ragnarson, P., Svanberg, S., Hernandez A., 1998. Atmospheric mercury concentrations and fluxes in the Almadén district (Spain). Atmos. Environ. 32 (22), 3897-3904.

Fitzgerald, W.F., Engstrom, D.R., Mason, R.P., Nater, E.A., 1998. The case for atmospheric mercury contamination in remote areas. Crit. Rev. Environ. Sci. Technol. 32 (1), 1-7.

Foucher, D., Hintelmann, H., 2006. High-precision measurement of mercury isotope ratio in sediments using cold-vapor generation multi-collector inductively coupled plasma mass spectrometry. Anal. Bioanal. Chem. 384, 1470-1478.

García-Sánchez, A., Murciego, A., Álvarez-Ayuso, E., Regina, I.S., Rodríguez-González, M.A 2009. Mercury in soils and plants in an abandoned cinnabar mining area (SW Spain). J. Hazard. Mater. 168, 1319-1324.

Gehrke, G.E., Blum, J.D., Marvin DiPasquale, M., 2011. Sources of mercury to San Francisco Bay surface sediment as revealed by mercury stable isotopes. Geochim. Cosmochim. Acta 75, 691-705.

Ghosh, S., Xu, Y., Humayun, M., Odom, L., 2008. Mass-independent fractionation of mercury isotopes in the environment. Geochem. Geophys. Geosyst. 9 (3), Q03004. http://dx.doi.org/10.1029/2007GC001827.

Ghosh, S., Schauble, E.A., Lacrampe Couloume, G., Blum, J.D., Bergquist, B.A., 2013. Estimation of nuclear volume dependent fractionation of mercury isotopes in equilibrium liquid-vapor evaporation experiments. Chem. Geol. 336, 5-12.

Gosar, M., Pirc, S., Bidovec, M., 1997. Mercury in the Idrijca River sediments as a reflection of mining and smelting activities of the Idrija mercury mine. J. Geochem. Explor. 58, 125-131.

Gosar, M., Šajn, R., Biester, H., 2006. Binding of mercury in soils and attic dust in the Idrija mercury mine area (Slovenia). Sci. Total. Environ. 369, 150-162.

Gratz, L.E., Keeler, G.J., Blum, J.D., Sherman, L.S., 2010. Isotopic composition and fractionation of mercury in Great Lakes precipitation and ambient air. Environ. Sci. Technol. 44 (20), 7764-7770

Gray, J.E., Theodorakos, P.M., Bailey, E.A., Turner, R.R., 2000. Distribution, speciation, and transport of mercury in stream-sediment, stream-water, and fish collected near abandoned mercury mines in southwestern Alaska, USA. Sci. Total. Environ. 260 (1-3), 21-33.

Gray, J.E., Greaves, I.A., Bustos, D.M., Krabbenhoft, D.P., 2003. Mercury and methylmercury contents in mine-waste calcine, water, and sediment collected from the Palawan Quicksilver Mine, Philippines. Environ. Geol. 43, 298-307.

Gray, J.E., Hines, M.E., Higueras, P.L., Adatto, I., Lasorsa, B.K., 2004. Mercury speciation and microbial transformations in mine wastes, stream sediments, and surface waters at the Almadén mining district, Spain. Environ. Sci. Technol. 38 (16), 4285-4292.

Gray, J.E., Plumlee, G.S., Morman, S.A., Higueras, P.L., Crock, J.G., Lowers, H.A., Witten, M.L., 2010. In vitro studies evaluating leaching of mercury from mine waste calcine using simulated human body fluids. Environ. Sci. Technol. 44, 4782-4788.

Gray, J.E., Pribil, M.J., Van Metre, P.C., Borrok, D.M., Thapalia, A., 2013. Identification of contamination in a lake sediment core using $\mathrm{Hg}$ and $\mathrm{Pb}$ isotopic compositions, Lake Ballinger, Washington, USA. Appl. Geochem. 29, 1-12.

Hernandez, A., Jebrak, M., Higueras, P., Oyarzun, R., Morata, D., Munha, J., 1999. The Almadén mercury mining district, Spain. Miner. Deposita 34, 539-548.

Higueras, P., Oyarzun, R., Lunar, R., Sierra, J., Parras, J., 1999. The Las Cuevas deposit, Almadén district (Spain): an unusual case of deep-seated advanced argillic alteration related to mercury mineralization. Miner. Deposita 34 (2), 211-214.

Higueras, P., Oyarzun, R., Biester, H., Lillo, J., Lorenzo, S., 2003. A first insight into mercury distribution and speciation in soils from the Almadén mining district, Spain. J. Geochem. Explor. 80, 95-104.
Higueras, P., Oyarzun, R., Lillo, J., Sánchez-Hernández, J.C., Molina, J.A., Esbrí, J.M., Lorenzo, S., 2006. The Almadén district (Spain): anatomy of one of the world's largest Hgcontaminated sites. Sci. Total. Environ. 236 (1-3), 112-124.

Higueras, P., Esbrí, J.M., Oyarzun, R., Llanos, W., Martínez-Coronado, A., Lillo, J., LópezBerdonces, M.A. García-Noguero, E.M. 2013. Industrial and natural sources of gaseous elemental mercury in the Almadén district (Spain): an updated report on this issue after the ceasing of mining and metallurgical activities in 2003 and major land reclamation works. Environ. Res. 125, 197-208.

Hintelmann, H., Lu, S.Y., 2003. High precision isotopic ratio measurements of mercury isotopes in cinnabar ores using multi-collector inductively coupled plasma mass spectrometry. Analyst 128, 635-639.

Hudson, R.J.M., Gherini, S.A., Fitzgerald, W.F., Porcella, D.B., 1995. Anthropogenic influences on the global mercury cycle: a model-based analysis. Water Air Soil Pollut. 80, 265-272.

Kim, C.S., Brown Jr., G.E., Rytuba, J.J., 2000. Characterization and speciation of mercurybearing mine wastes using X-ray absorption spectroscopy. Sci. Total. Environ. 261, 157-168.

Kim, C.S., Bloom, N.S., Rytuba, J.J., Brown Jr., G.E., 2003. Mercury speciation by X-ray absorption fine structure spectroscopy and sequential chemical extractions: a comparison of speciation methods. Environ. Sci. Technol. 37 (22), 5102-5108.

Kocman, D., Horvat, M., Pirrone, N., Cinnirella, S., 2013. Contribution of contaminated sites to the global mercury budget. Environ. Res. 125, 160-170.

Lamborg, C.H., Fitzgerald, W.F., O'Donnell, J., Torgersen, T., 2002. A non-steady-state compartmental model of global-scale mercury biogeochemistry with interhemispheric atmospheric gradients. Geochim. Cosmochim. Acta 66, 1105-1118.

Lin, Y., Larssen, T., Vogt, R.D., Feng, X., 2010. Identification of fractions of mercury in water, soil and sediment from a typical Hg mining area in Wanshan, Guizhou province, China. Appl. Geochem. 25, 60-68

Llanos, W., Kocman, D., Higueras, P., Horvat, M., 2011. Mercury emission and dispersion models from soils contaminated by cinnabar mining and metallurgy. J. Environ. Monit. 13, 3460-3468

Martínez-Coronado, A., Oyarzun, R., Esbrí, J.M., Llanos, W., Higueras, P., 2011. Sampling high to extremely high $\mathrm{Hg}$ concentrations at the Cerco de Almadenejos, Almadén mining district (Spain): the old metallurgical precinct (1794 to $1861 \mathrm{AD}$ ) and surrounding areas. J. Geochem. Explor. 109, 70-77.

Mason, R.P., Fitzgerald, W.F., Morel, F.M.M., 1994. The biogeochemical cycling of elemental mercury; anthropogenic influences. Geochim. Cosmochim. Acta 58 (15), 3191-3198.

Porcella, D.B., 1994. Mercury in the environment: biogeochemistry. In: Watras, C.J., Huckabee, J.W. (Eds.), Mercury Pollution. CRC Press, Boca Raton, pp. 3-19.

Rimondi, V., Gray, J.E., Costagliola, P., Vaselli, O., Lattanzi, P., 2012. Concentration, distribution, and translocation of mercury and methylmercury in mine-waste, sediment, soil, water, and fish collected near the Abbadia San Salvatore mercury mine, Monte Amiata district, Italy. Sci. Total. Environ. 414, 318-327.

Rolison, J.M., Landing, W.M., Luke, W., Cohen, M., Salters, V.J.M., 2013. Isotopic composition of species-specific atmospheric Hg in a coastal environment. Chem. Geol. 336, 37-49.

Rytuba, J.J., 2000. Mercury mine drainage and processes that control its environmental impact. Sci. Total. Environ. 260 (1-3), 57-71.

Schauble, E.A., 2007. Role of nuclear volume in driving equilibrium stable isotope fractionation of mercury, thallium, and other very heavy elements. Geochim. Cosmochim. Acta 71, 2170-2189.

Sherman, L.S., Blum, J.D., Nordstrom, D.K., McCleskey, R.B., Barkay, T., Vetriani, C., 2009. Mercury isotopic composition of hydrothermal systems in the Yellowstone Plateau volcanic field and Guaymas Basin sea-floor rift. Earth Planet. Sci. Lett. 279, 86-96.

Sherman, L.S., Blum, J.D., Johnson, K.P., Keeler, G.J., Barres, J.A., Douglas, T.A., 2010. Massindependent fractionation of mercury isotopes in Arctic snow driven by sunlight. Nat. Geosci. 3, 173-177.

Smith, C.N., Kesler, S.E., Bjorn, K., Blum, J.D., 2005. Mercury isotope fractionation in fossil hydrothermal systems. Geology 33 (10), 825-828.

Smith, C.N., Kesler, S.E., Blum, J.D., Rytuba, J.J., 2008. Isotope geochemistry of mercury in source rocks, mineral deposits and spring deposits of the California Coast Ranges, USA. Earth Planet. Sci. Lett. 269, 399-407.

Sonke, J.E., Zambardi, T., Toutain, J.-P., 2008. Indirect gold trap-MC-ICP-MS coupling for Hg stable isotope analysis using a syringe injection interface. J. Anal. At. Spectrom. 23 (4), 569-573.

Sonke, J.E., Schäfer, J., Chmeleff, J., Audry, S., Blanc, G., Dupré, B., 2010. Sedimentary mercury stable isotope records of atmospheric and riverine pollution from two major European heavy metal refineries. Chem. Geol. 279, 90-100.

Stetson, S.J., 2009. Analytical Methods for the Evaluation of Environmental Contamination by Perchlorate and Mercury. (Ph.D. Dissertation Thesis) Colorado School of Mines, Golden, Colorado (162 pp.).

Stetson, S.J., Gray, J.E., Wanty, R.B., Macalady, D.L., 2009. Isotopic variability of mercury in ore, mine-waste calcine, and leachates of mine-waste calcine from areas mined for mercury. Environ. Sci. Technol. 43, 7331-7336.

Sun, R., Heimbürger, L.E., Sonke, J.E., Liu, G., Amouroux, D., Berail, S., 2013. Mercury stable isotope fractionation in six utility boilers of two large coal-fired power plants. Chem. Geol. 336, 103-111

Yin, R., Feng, X., Wang, J., Li, P., Liu, J., Zhang, Y., Chen, J., Zheng, L., Hu, T., 2013. Mercury speciation and mercury isotope fractionation during ore roasting process and their implication to source identification of downstream sediment in the Wanshan mercury mining area, SW China. Chem. Geol. 336, 72-79.

Young, E.Y., Galy, A., Nagahara, H., 2002. Kinetic and equilibrium mass-dependent isotope fractionation laws in nature and their geochemical and cosmochemical consequence. Geochim. Cosmochim. Acta 66, 1095-1104.

Zambardi, T., Sonke, J.E., Toutain, J.P., Sortino, F., Shinohara, H., 2009. Mercury emissions and stable isotopic compositions at Vulcano Island (Italy). Earth Planet. Sci. Lett. $277,236-243$. 